\title{
Molecular characterization of Listeria monocytogenes isolated from fresh seafood samples in Iran
}

Hassan Momtaz ${ }^{* *}$ and Shole Yadollahi ${ }^{2}$

\begin{abstract}
Background: Among all species of Listeria, Listeria monocytogenes (L. monocytogenes) is a major pathogenic microorganism of humans and animals and L. ivanovii is rarely pathogenic for humans. The objective of this study was to isolate and characterize Listeria species and to determine the frequencies of virulence genes in $L$. monocytogenes serotypes in fresh fish, shrimp, crab and lobster in Isfahan and Shahrekord, Iran.

Methods: From September 2010 to April 2011, a total of 300 marine food samples were purchased from supermarkets of Isfahan and Shahrekord cities, Iran. All samples were cultured and the positive samples for $L$. monocytogenes were analyzed for presence of serotypes and virulence genes.
\end{abstract}

Results: From the total 300 samples, 23 (10.45\%) fresh fish and 1 (2.5\%) shrimp samples were positive for Listeria spp., but there were no positive lobster and crab samples for Listeria species. Only L. monocytogenes was isolated from 17 fish (7.25\%) and 1 shrimp (2.5\%) samples while L. innocua, L. ivanovii and L. seeligeri only detected in fish samples (2 (0.9\%), $3(1.36 \%)$ and $1(0.45 \%))$, respectively. The plcA, prfA, actA, hlyA and iap virulence genes were detected in all of the $18 \mathrm{~L}$. monocytogenes isolates. Totally, the $4 \mathrm{~b}, 1 / 2 \mathrm{a}$ and $1 / 2 \mathrm{~b}$ serotypes were detected in $66.66 \%, 5.55 \%$ and $27.77 \%$ bacterial isolates, respectively.

Conclusions: Consumption of these sea foods, either raw or undercooked, may contribute to food-borne illness due to L. monocytogenes in Iran. The hygienic quality of sea food products should be observe.

Virtual slides: The virtual slide(s) for this article can be found here: http://www.diagnosticpathology.diagnomx.eu/ vs/3422944359800606

Keywords: Listeria spp, Listeria monocytogenes, Virulence factors, Serotypes, Seafood, Iran

\section{Background}

Some-food borne diseases are well recognized but their prevalence rate has been increased these days. Totally, Campylobacter species (Campylobacter spp.), Salmonella spp., Listeria species (Listeria spp.), and Escherichia coli O157:H7 have been generally found to be responsible for majority of food- borne outbreaks [1,2]. Listeria spp. are ubiquitous, Gram-positive, facultative anaerobic, nonspore-forming, rod-shaped bacteria. Listeria monocytogenes (L. monocytogenes), L. ivanovii, $L$. innocua, $L$. seeligeri, $L$.

\footnotetext{
* Correspondence: hamomtaz@yahoo.com

'Department of Microbiology, College of Veterinary Medicine, ShahreKord Branch, Islamic Azad University, ShahreKord, Iran

Full list of author information is available at the end of the article
}

welshimeri, and $L$. grayi are the most important species in the genus Listeria [3].

The hemolytic species of Listeria such as $L$. monocytogenes, L. ivanovii and L. seeligeri, are associated with human pathogenicity. Both L. ivanovii and $L$. seeligeri are the rare causes of human infection. These two pathogens are responsible for meningitis in a nonimmunocompromised adult [4]. The L. monocytogenes has been involved in known food-borne outbreaks of listeriosis $[5,6]$ however, there are some reports of $L$. seeligeri and L. ivanovii causing food-borne illness in humans $[7,8]$. The L. monocytogenes is responsible for listeriosis which can known by several complications including abortion, bacteraemia, sepsis, and meningoencephalitis $[9,10]$. The ability of $L$. monocytogenes to survive in a wide range of

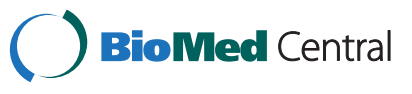


environmental conditions like grow at refrigerator temperatures is undeniable.

Approximately, 2,500 cases of human listeriosis occur annually in the United States, resulting in 500 deaths [11]. Since, Listeria spp. has been isolated from a wide range of sea-food products such as shrimp [12], crab [13], cold-smoked rainbow trout [14], fish products [15] and lobster [16]. Multiple virulence factors such as hemolysin (hlyA), phosphatidylinositol phospholipase C (plcA), actin polymerization protein (actA) and invasive associated protein (iap) are important in the pathogenesis of $L$. monocytogenes infections [17]. The $1 / 2 \mathrm{a}, 1 / 2 \mathrm{~b}$, and $4 \mathrm{~b}$ are the most commonly detected serotypes of Listeria spp. isolated from various types of clinical samples [18]. Isolation and characterization of Listeria species is done mainly by cultural, biochemical and molecular methods. There is a need for quick and reliable molecular methods such as the Polymerase Chain Reaction (PCR) for Listeria detection.

Sea-foods are so popular among Iranian people. The epidemiology and prevalence of Listeria spp. is essentially unknown in Iranian sea-foods. Therefore, the present study was carried out in order to detection and characterization of Listeria spp. and study the frequency of virulence genes and serotypes of L. monocytogenes isolated from fresh fish, crab, shrimp and lobster using cultural, biochemical and molecular techniques.

\section{Methods}

\section{Bacterial strains}

The standard strains of L. monocytogenes (PTCC 1298), Listeria ivanovii subsp. ivanovii (PTCC 1303), Staphylococcus aureus (PTCC 1113) and Rhodococcus equi (PTCC 1633) were obtained from the Iranian Research Organization for Science and Technology, Iran and used in culture and PCR methods.

\section{Sample collection}

From September 2010 to April 2011, a total of 300 seafood samples including fresh fish $(\mathrm{n}=120)$, crab $(\mathrm{n}=20)$, lobster $(\mathrm{n}=40)$ and shrimp $(\mathrm{n}=120)$ were collected from the supermarkets and retailers of Isfahan and Shahrekord cities, Iran. Samples were transferred to the Food Microbiology Laboratory at the Islamic Azad University of Shahrekord Branch in portable insulated cold-boxes. Samples were analyzed on a day of collection.

\section{Isolation and Identification of Listeria}

Listeria spp. were isolated from seafood samples according to ISO 11290 protocol [19]. Then all isolates were subjected to standard biochemical tests including Gram staining, catalase test, motility test at $25^{\circ} \mathrm{C}$ and $37^{\circ} \mathrm{C}$, acid production from glucose, manitol, rhamnose, zylose, $\alpha$-methyl-D-mamoside, and nitrate reduction, hydrolysis of esculin, MR/VP test, ß-hemolytic activity, and CAMP test [20].

\section{Phenotypic characterization}

1- Haemolysis on sheep blood agar (SBA)

All the Listeria isolates were tested for the type ( $\alpha$ or $\beta)$ and the degree (narrow or wider) of hemolysis on $7 \%$ sheep blood agar (SBA). Briefly, the isolates were streaked onto $7 \% \mathrm{SBA}$ plates and incubated at $37^{\circ} \mathrm{C}$ in a humidified chamber for $24 \mathrm{~h}$ and examined for hemolytic zones around the colonies. Interpretation of the hemolytic reaction was based on the characteristic $\beta$-hemolysis in the form of wider and clear zone of hemolysis representing $L$. ivanovii while a narrow zone of $\alpha$-hemolysis was the characteristic of L. monocytogenes or L. seeligeri [21].

2- Christie, Atkins, Munch and Petersen (CAMP) test All the Listeria isolates were tested by CAMP test. Briefly, the standard strains of Staphylococcus aureus and Rhodococcus equi were grown overnight on 7\% SBA plates at $37^{\circ} \mathrm{C}$ and their colonies were again streaked onto freshly prepared 7\% SBA plates in a manner such that the streaks were wide apart and parallel to each other. In between the parallel streaks of S. aureus and R. equi the Listeria isolates were streaked at $90^{\circ} \mathrm{C}$ angle and $3 \mathrm{~mm}$ apart before incubating them at $37^{\circ} \mathrm{C}$ for $24 \mathrm{~h}$. The plates were examined for enhancement of the hemolytic zone from partial hemolysis to a wider zone of complete hemolysis, if any, between a Listeria strain and the S. aureus or R. equi strain owing to the synergistic effect of their hemolysins in case of a CAMPpositive reaction. The Listeria isolates with CAMPpositivity against $S$. aureus were characterized as $L$. monocytogenes and those with CAMP positivity against $R$. equi were characterized as L. ivanovii [21].

3- Phosphatidyiinositol- specific phospholipase $\mathrm{C}$ (PI-PLC) assay

All the biochemically characterized Listeria isolates were assayed for PI-PLC activity as per the method of Leclercq [22] with certain modifications. In brief, the Listeria isolates were grown overnight onto 7\% SBA plates at $37^{\circ} \mathrm{C}$. All Listeria isolates were streaked on $L$. mono differential agar (Hi Media Ltd, Mumbai, India) in order to assess PI-PLC activity. The inoculated plates were incubated at $37^{\circ} \mathrm{C}$ in a humidified chamber for $24 \mathrm{~h}$. On L. mono differential agar, light blue colonies showing a halo formation around the inoculation site were considered positive for PI-PLC assay.

4- Phosphatidyiinositol- specific phospholipase $\mathrm{C}$ (PC-PLC) assay 
The eggyolk opacity test was done to examine the phosphatidylcholine-specific phospholipase $\mathrm{C}$ (PCPLC) activity of the isolates. Tryptic soy agar (Hi Media Ltd. Mumbai, India) plates were prepared with 2.5 per cent egg-yolk emulsion (Hi Media Ltd. Mumbai, India) and 2.5 per cent $\mathrm{NaCl}, \mathrm{pH}$ 6.5-7.

Listeria isolates were streaked onto the agar surfaces and incubated at $37^{\circ} \mathrm{C}$ for $36-72 \mathrm{~h}$ and observed for formation of opaque zones surrounding the growth [23].

\section{DNA extraction}

Chromosomal DNA was prepared using the Zhang et al. [24] method. Briefly, $1 \mathrm{~mL}$ of overnight culture (from brain-heart infusion) broth was transferred to $1.5-\mathrm{mL}$ microfuge tube and centrifuged at 8,000 rpm for $5 \mathrm{~min}$, and the supernatant was discarded and $500 \mu \mathrm{L}$ of cetyl trimethylammonium bromide buffer at $60^{\circ} \mathrm{C}$ was added to the microfuge tube containing the bacterial pellet; the mixture was held in water bath at $64^{\circ} \mathrm{C}$ for $20 \mathrm{~min}$. During incubation, the mixture was briefly mixed several times. After incubation, $500 \mu \mathrm{L}$ of chloroform/octanol (24:1) was added and mixed vigorously followed by centrifugation at 3,000 rpm for $5 \mathrm{~min}$. The supernatant was transferred to a clean microfuge tube, and an equal volume of ice-cold isopropanol was added and kept on ice bath for 2-h precipitation. The solution was then centrifuged at $8,000 \mathrm{rpm}$ for $8 \mathrm{~min}$. The aqueous phase was discarded and the DNA pellet was rinsed with $80 \%$

Table 1 Primers for amplification of virulence associated genes, Listeria spp. and serotypes of $L$. monocytogenes

\begin{tabular}{|c|c|c|c|c|}
\hline Primer name & Primer sequence $\left(5^{\prime}-3^{\prime}\right)$ & Target & Size of product (bp) & References \\
\hline Lis1B & TTATACGCGACCGAAGCCAAC & L. innocua & 870 & {$[26]$} \\
\hline Ino2 & ACTAGCACTCCAGTTGTTAAAC & & & \\
\hline Lis1B & TTATACGCGACCGAAGCCAAC & $L$. & 660 & [26] \\
\hline MonoA & CAAACTGCTAACACAGCTACT & monocytogenes & & \\
\hline Lis1B & TTATACGCGACCGAAGCCAAC & L. ivanovii & 1100 & [26] \\
\hline Iva1 & CTACTCAAGCGCAAGCGGCAC & & & \\
\hline Lis1B & TTATACGCGACCGAAGCCAAC & L. seeligeri & 1100 & [26] \\
\hline Sel1 & TACACAAGCGGCTCCTGCTCAAC & & & \\
\hline Lis1B & TTATACGCGACCGAAGCCAAC & L. welshimeri & 1050 & [26] \\
\hline Wel1 & CCCTACTGCTCCAAAAGCAGCG & & & \\
\hline Lis1B & TTATACGCGACCGAAGCCAAC & L. grayi & 480 & [26] \\
\hline Mural & GTGATTTCTGCTTGCCATAG & & & \\
\hline prsF & GCTGAAGAGATTGCGAAAGAAG & All L. monocytogenes serovares & 370 & {$[27]$} \\
\hline prsR & CAAAGAAACCTTGGATTTGCGG & & & \\
\hline Imo0737F & AGGGCTTCAAGGACTTACCC & L. monocytogenes serovar $1 / 2 a$ & 691 & {$[27]$} \\
\hline Imo0737R & ACGATTTCTGCTTGCCATTC & & & \\
\hline ORF2819F & AGCAAAATGCCAAAACTCGT & L. monocytogenes serovar $1 / 2 b$ & 471 & {$[27]$} \\
\hline ORF2819R & CATCACTAAAGCCTCCCATTG & & & \\
\hline ORF2110F & AGTGGACAATTGATTGGTGAA & L. monocytogenes serovar $4 b$ & 597 & {$[27]$} \\
\hline ORF2110R & CATCCATCCCTTACTITGGAC & & & \\
\hline plc A-F & CTGCTTGAGCGTTCATGTCTCCATCCCCC & plcA gene & 1484 & [28] \\
\hline plc A-R & CATGGGTTTCACTCTCCTTCTAC & & & \\
\hline prf A-F & CTGTTGGAGCTCTTCTTGGTGAAGCAATCG & prfa gene & 1060 & [28] \\
\hline prf A-R & AGCAACCTCGGTACCATATACTAACTC & & & \\
\hline act A-F & CGCCGCGGAAATTAAAAAAAGA & actA gene & 839 & [29] \\
\hline act A-R & ACGAAGGAACCGGGCTGCTAG & & & \\
\hline hly A-F & GCAGTTGCAAGCGCTTGGAGTGAA & hlyA gene & 456 & [30] \\
\hline hly A-R & GCAACGTATCCTCCAGAGTGATCG & & & \\
\hline lap-F & ACAAGCTGCACCTGTTGCAG & lap gene & 131 & {$[31]$} \\
\hline lap-R & TGACAGCGTGTGTAGTAGCA & & & \\
\hline
\end{tabular}


Table 2 Prevalence of Listeria spp. in marine foods in Iran

\begin{tabular}{ccccccc}
\hline $\begin{array}{c}\text { Type of } \\
\text { sample }\end{array}$ & $\begin{array}{c}\text { No. of } \\
\text { samples }\end{array}$ & $\begin{array}{c}\text { No. (\%) of Listeria } \\
\text { spp. }\end{array}$ & $\begin{array}{c}\text { No. (\%) of } L . \\
\text { monocytogenes }\end{array}$ & $\begin{array}{c}\text { No. (\%) of } L . \\
\text { innocua }\end{array}$ & $\begin{array}{c}\text { No. (\%) of } L . \\
\text { ivanovii }\end{array}$ & $\begin{array}{c}\text { No. (\%) of } L . \\
\text { seeligeri }\end{array}$ \\
\hline Fish & 220 & $23(10.45)$ & $17(7.72)$ & $2(0.9)$ & $3(1.36)$ & - \\
Shrimp & 40 & $1(2.5)$ & $1(2.5)$ & - & - & - \\
Lobster & 20 & - & - & - & - & - \\
Crab & 20 & - & $18(6)$ & $2(0.66)$ & $3(1)$ & - \\
Total & 300 & $24(8)$ & & & & - \\
\hline
\end{tabular}

ethanol, air- dried and resuspended in $50 \mu \mathrm{L}$ of double distilled water and used for PCR [25].

PCR condition for detection of Listeria spp. L. monocytogenes serotypes and virulence genes of $L$. monocytogenes

The details of the primers sequences for amplification of Listeria spp., L. monocytogenes, its virulence genes and serotypes are shown in Table 1. DNA amplification was performed in a DNA thermal cycler (Eppendrof Mastercycler 5330; Eppendorf-Nethel-Hinz GmbH, Hamburg, Germany). The PCR programs and their volumes for L. monocytogenes, L. innocua, L. ivanovii, L. seeligeri, L. welshimeri, and L. grayi amplification were studied using the method which was described by Bubert et al. [26].

The PCR was standardized for the detection of virulence associated genes of $L$. monocytogenes by previously described methods [26-31].

The multiplex PCR assay was standardized for the detection of three major serovars of L. monocytogenes namely $1 / 2 \mathrm{a}, 1 / 2 \mathrm{~b}$ and $4 \mathrm{~b}$, using the method which was described by Doumith et al. [27]. The PCR products were analyzed by $1.5 \%$ agarose gel electrophoresis and the specific DNA bands were visualized using ethidium bromide staining under UV illumination.

\section{Results and discussion}

All of the three houndred sea-food samples were studied for presence of Listeria spp. Totally, twenty three fresh fish samples $(10.45 \%)$ and only one shrimp sample (2.5\%) were positive for Listeria spp. there were no positive results for lobster and crab samples. Also, 17 fresh fish samples (7.72\%) were positive for the L. monocytogenes. Totally, the frequency of L. innocua, L. ivanovii and L. seelgeri in fresh fish samples of our study were $0.9 \%, 1.36 \%$ and $0.45 \%$, respectively (Table 2). One of the shrimp samples of our study was positive for L. monocytogenes (2.5\%).

All the 18 isolates of $L$. monocytogenes showed the characteristic enhancement of hemolytic zone with $S$. aureus. Also, all of the 18 isolates of L. monocytogenes were found to be pathogenic by PI- PLC and PC-PLC.

The five virulence-associated genes ( $p l c A, \operatorname{prf} A, \operatorname{act} A$, hlyA and iap) were detected in all of the $18 \mathrm{~L}$. monocytogenes isolates. The most commonly detected serotype in L. monocytogenes isolates was $4 \mathrm{~b}$, which occurred in $12 / 18(66.66 \%)$ samples. The frequency of $1 / 2 \mathrm{a}$ and $1 / 2 \mathrm{~b}$ serotypes were $5.55 \%$ and $27.77 \%$, respectively (Table 3 ).

Listeriosis is one of the most important zoonotic bacterial diseases with worldwide distribution. Disease has considerable economic and public health importance.

Listeria monocytogenes has been described as opportunistic pathogen mainly affecting children, pregnant women, and aged and immune-challenged individuals [32,33]. Also, a wide variety of animals including sheep, cattle, goats, pigs, rabbits, mice, birds, and fish are also infected with $L$. monocytogenes. An atypical foodborne listeriosis has a range of 25 to $30 \%$ in susceptible populations [34]. Since 1975, foodborne listeriosis outbreaks have been reported in industrialized countries of Europe, North America and Oceania with few or no reports from Africa, Asia and Latin America [35,36]. Despite the high importance of sea-foods listeriosis, there were few published data about its distribution in fish and shrimp samples of Iran $[12,37,38]$.

Our results revealed that $6 \%, 1 \%, 0.66 \%$ and $0.66 \%$ of Iranian sea-food samples were positive for $L$. monocytogenes, L. ivanovii, L. innocua and seeligeri, respectively. Rahimi et al. (2012) reported that $L$. monocytogenes and L. innocua were detected in $1.9 \%$ and $5.7 \%$ of the frozen and fresh sea-food samples,

Table 3 Frequency of Listeria monocytogenes serotypes in marine foods in Iran

\begin{tabular}{|c|c|c|c|c|}
\hline $\begin{array}{l}\text { Type of } \\
\text { sample }\end{array}$ & No. (\%) of L. monocytogenes & $4 b$ & $1 / 2 a$ & $1 / 2 b$ \\
\hline Fish & 17 & $11(64.70 \%)$ & $1(5.88 \%)$ & $5(29.41 \%)$ \\
\hline Shrimp & 1 & $1(100 \%)$ & - & - \\
\hline Total & 18 & $12(66.66 \%)$ & $1(5.55 \%)$ & $5(27.77 \%)$ \\
\hline
\end{tabular}


respectively [12]. Zarei et al. [38] reported the low frequency of $L$. monocytogenes in Iranian sea-food samples (1.4\%). Also, Akhondzadeh Basti et al. [37] reported that $2.6 \%$ of smoked fish samples were positive for L. monocytogenes. Study in Urumia, Iran showed that $12.37 \%$ of collected fish samples were positive for Listeria [39]. They showed that $21 \%$ and $29 \%$ of isolates were L. monocytogenes and L. ivonoi [39]. The results of our study and several Iranian reports showed that the Listeria spp. had the low frequency in Iranian sea-foods.

An overall prevalence of L. monocytogenes was 3\% in European fish [40] but Miettinen and Wirtanen [41] reported that the prevalence of Listeria spp. and $L$. monocytogenes in pooled unprocessed fresh rainbow trout were $35 \%$ and $14.6 \%$, respectively. The $L$. innocua was the most common Listeria spp. in the fishes of Greece country [42]. The incidence of Listeria spp. in Turkey was $30 \%$ in freshwater samples and $10.4 \%$ in marine fish samples. Also, $44.5 \%$ and $83.5 \%$ of all isolates were $L$. monocytogenes and $L$. murrayi, respectively [43]. These high differences in prevalence of Listeria spp. in sea-foods maybe due the facts that type of samples (fish, shrimp, crab, oyster and lobster), number of samples, methods of sampling, method of experiment, geographical area and even climate of area which samples were collected are different in each investigation.

All of the detected L. monocytogenes bacteria had plcA, $\operatorname{prfA}$, actA, $h l y A$ and iap putative virulence genes. Unfortunately, there were no previously published data about detection of L. monocytogenes virulence factors in sea-food products but their high frequencies in the bacterial strains of our study can lead to adhesion, invasion and epithelial damage to the human digestive system.

The most commonly detected serotypes in $L$. monocytogenes isolates our study was $4 \mathrm{~b}$ (66.66\%), followed by $1 / 2 \mathrm{~b}(27.77 \%)$ and $1 / 2 \mathrm{a}(5.55 \%)$. Similar results have been reported previously $[26,27,44]$. Previous report of the National Reference Center in France showed that over than $98 \%$ of 5,000 isolates of $L$. monocytogenes harbored $1 / 2 \mathrm{a}, 1 / 2 \mathrm{~b}, 1 / 2 \mathrm{c}$, and $4 \mathrm{~b}$ serotypes [26].

\section{Conclusions}

The results of our study showed that severe controls should be performed on the hygienic quality of Iranian sea-foods. These products are well contaminated with Listeria spp. and especially $L$. monocytogenes. Contact with intestinal contents, cross contamination from infected staffs, using contaminated equipments, fish manipulation and inappropriate transportation are the main factors for sea-foods contamination. Also, may be some food safety and quality standards need to be applied and performed in most of Iranian supermarkets and even fishing centers to control growth of Listeria during fishing, collection, transmission, distribution and storage periods. Suitable cocking of sea-foods can diminish the microbial loads of these products especially for Listeria spp.

\section{Competing interests}

Both authors declare that they have no competing interests.

\section{Authors' contributions}

The DNA extraction, PCR techniques, statistical analysis, writing of manuscript and supporting of project was performed by HM and samples collection and culture was performed by SY. Both authors read and approved the final manuscript.

\section{Acknowledgements}

The authors thank Mr. M. Momeni, and S. Safari at the Biotechnology Research Center and Microbiology laboratory of the Islamic Azad University of Shahrekord, for their sincere technical support. This work was supported by Islamic Azad University of Falavarjan Branch in Iran.

\section{Author details}

${ }^{1}$ Department of Microbiology, College of Veterinary Medicine, ShahreKord Branch, Islamic Azad University, ShahreKord, Iran. ${ }^{2}$ Post graduated of Master of Science of Microbiology, Falavarjan Branch, Islamic Azad University,

Falavarjan, Iran.

Received: 27 April 2013 Accepted: 27 August 2013

Published: 13 September 2013

\section{References}

1. Alocilja EC, Radke SM: Market analysis of biosensors for food safety. Biosens Bioelectron 2003, 18(5-6):841-846.

2. Chemburu S, Wilkins E, Abdel-Hamid I: Detection of pathogenic bacteria in food samples using highly-dispersed carbon particles. Biosens Bioelectron 2005, 21(3):491-499.

3. Rocourt J, Cossart P: Listeria monocytogenes. In Food microbiology fundamentals and frontiers. Edited by Doyle MP, Beuchat LR, Montville TJ. Washington, D.C.: ASM Press; 1997:337-352.

4. Lovett J, Twedt R: Listeria. Outstanding symposia in food science and technology. Food Technol 1988, 8:188-191.

5. Ingianni A, Floris M, Palomba P, Madeddu MA, Quartuccio M, Pompei R: Rapid detection of Listeria monocytogenes in foods, by a combination of PCR and DNA probe. Mol Cell Probes 2001, 15(5):275-280.

6. Moharem AS, Charith Raj AP, Janardhana GR: Incidence of Listeria species in seafood products of Mysore, India. J Food Saf 2007, 27(4):362-372.

7. Cummins AJ, Fielding AK, McLauchlin J: Listeria ivanovii infection in a patient with AIDS. J Infect 1994, 28(1):89-91.

8. Gasanov U, Hughes D, Hansbro PM: Methods for the isolation and identification of Listeria spp. and Listeria monocytogenes: a review. FEMS Microbiol Rev 2005, 29(5):851-875.

9. Khelef N, Lecuit M, Buchrieser C, Cabanes DE, Dussurget O, Cossart P: Listeria monocytogenes and the genus Listeria. Proc Natl Acad Sci USA 2006, 4:404-476.

10. Sasakawa C: Molecular mechanisms of bacterial infection via the gut. Curr Top Microbiol Immunol 2009, 337:173-195.

11. Mead PS, Slutsker L, Dietz V, McCaig LF, Bresee JS, Shapiro C: Food-related illness and death in the United States. Emerg Infect Dis 1999, 5(5):607-625.

12. Rocourt J, Jacquet C, Reilly A: Epidemiology of human listeriosis and seafoods. Int J Food Microbiol 2000, 62(3):197-209.

13. Rahimi E, Shakerian A, Raissy M: Prevalence of Listeria species in fresh and frozen fish and shrimp in Iran. Ann Microbiol 2012, 62(1):37-40.

14. Pagadala S, Parveen S, Rippen T, Luchansky JB, Call JE, Tamplin ML: Prevalence, characterization and sources of Listeria monocytogenes in blue crab (Callinectus sapidus) meat and blue crab processing plants. Food Microbiol 2012, 31(2):263-270.

15. Ericsson H, Eklöw A, Danielsson-Tham ML, Loncarevic S, Mentzing LO, Persson I, Unnerstad $H$, Tham W: An outbreak of listeriosis suspected to have been caused by rainbow trout. J Clin Microbiol 1997, 35(11):2904-2907. 
16. Yildirim S, Lin W, Hitchins AD, Jaykus LA, Altermann E, Klaenhammer TR, Kathariou S: Epidemic clone I-specific genetic markers in strains of Listeria monocytogenes serotype $4 \mathrm{~b}$ from foods. Appl Environ Microbiol 2004, 70(7):4158-4164.

17. Rawool DB, Malik SVS, Barbuddhe SB, Shakuntala I, Aurora R: A multiplex PCR for detection of virulence associated genes in Listeria monocytogenes. Int J Food Saf 2007, 9:56-62.

18. Borucki MK, Call DR: Listeria monocytogenes serotype identification by PCR. J Clin Microbiol 2003, 41(12):5537-5540.

19. Scotter SL, Langton S, Lombard B, Schulten S, Nagelkerke N, In't Veld PH, Rollier P, Lahellec C: Validation of ISO method 11290 part 1-detection of Listeria monocytogenes in foods. Int J Food Microbiol 2001, 64(3):295-306.

20. Aygun O, Pehlivanlar S: Listeria spp. in the raw milk and dairy products in Antakya, Turkey. Food Control 2006, 17(8):676-679.

21. Yadav MM, Roy A, Bhanderi B, Joshi C: Pheno-genotypic characterization of Listeria monocytogenes from bovine clinical mastitis. Buffalo Bull 2010, 29(1):29-38.

22. Leclercq A: Atypical colonial morphology and low recoveries of Listeria monocytogenes strains on Oxford, PALCAM, Rapid'L.mono and ALOA solid media. J Microbiol Methods 2004, 57(2):251-258

23. Coffey A, Rombouts FM, Abee T: Influence of environmental parameters on phosphatidylcholine phospholipase $C$ production in Listeria monocytogenes: a convenient method to differentiate $\mathrm{L}$. monocytogenes from other Listeria species. App/ Environ Microbiol 1996, 62(4):1252-1256.

24. Zhang YP, Uyemoto JK, Kirkpatrick BC: A small-scale procedure for extracting nucleic acids from woody plants infected with various phytopathogens for PCR assay. J Virol Methods 1998, 71(1):45-50.

25. Swetha CS, Madhava Rao T, Krishnaiah N, Vijaya Kumar A: Detection of Listeria monocytogenes in fish samples by PCR assay. Ann Biolog Res 2012, 3(4):1880-1884.

26. Bubert A, Hein I, Rauch M, Lehner A, Yoon B, Goebel W, Wagner M: Detection and differentiation of Listeria spp. by a single reaction based on multiplex PCR. App/ Environ Microbiol 1999, 65(10):4688-4692.

27. Doumith M, Buchrieser C, Glaser P, Jacquet C, Martin P: Differentiation of the major Listeria monocytogenes serovars by multiplex PCR. J Clin Microbiol 2004, 42(8):3819-3822.

28. Notermans SH, Dufrenne J, Leimeister-Wächter M, Domann E, Chakraborty T: Phosphatidylinositol-specific phospholipase $C$ activity as a marker to distinguish between pathogenic and nonpathogenic Listeria species. Appl Environ Microbiol 1991, 57(9):2666-2670.

29. Suarez M, Vazquez-Boland JA: The bacterial actin nucleter protein ActA is involved in epithelial cell invasion by Listeria monocytogenes. PUBMED 2001 [Accession No. AF103807].

30. Paziak-Domańska B, Bogusławska E, Wieckowska-Szakiel M, Kotłowski R, Rózalska B, Chmiela M, Kur J, Dabrowski W, Rudnicka W: Evaluation of the API test, phosphatidylinositol-specific phospholipase $C$ activity and PCR method in identification of Listeria monocytogenes in meat foods. FEMS Microbiol Lett 1999, 171(2):209-214.

31. Furrer B, Candrian U, Hoefelein C, Luethy J: Detection and identification of Listeria monocytogenes in cooked sausage products and in milk by in vitro amplification of haemolysin gene fragments. J Appl Bacteriol 1991, 70(5):372-379.

32. Schlech WF 3rd: Foodborne listeriosis. Clin Infect Dis 2000, 31(3):770-775.

33. Liu D: Identification, subtyping and virulence determination of Listeria monocytogenes, an important foodborne pathogen. J Med Microbiol 2006, 55(Pt 6):645-659.

34. Laer AEV, Lima ASD, Trindade PDS, Andriguetto C, Destro MT, Silva WPD: Characterization of Listeria monocytogenes isolated from a fresh mixed sausage processing line in Pelotas-Rs by PAGE. Braz J Microbiol 2009, 40(3):574-582

35. Farber JM: Food and Agriculture Organization (FAO) expert consultation on the trade impact of Listeria in fish products. Amherst, Massachusetts, USA. 17-20 May 1999. Proceedings. Int J Food Microbiol 2000, 62(3):171-274.

36. Laciar AL, de Centorbi ONP: Listeria species in seafood: isolation and characterization of Listeria spp from seafood in San Luis, Argentina. Food Microbiol 2002, 19(6):645-651.

37. Akhondzadeh Basti A, Misaghi A, Zahraei Salehi T, Kamkar A: Bacterial pathogens in fresh smoked and salted Iranian fish. Food Control 2006, 17(3):183-188.
38. Zarei M, Maktabi S, Ghorbanpour M: Prevalence of Listeria monocytogenes, Vibrio parahaemolyticus, Staphylococcus aureus, and Salmonella spp. in seafood products using multiplex polymerase chain reaction. Foodborne Pathog Dis 2012, 9(2):108-112.

39. Modaresi R, Mardani K, Tukmechi A, Ownagh A: Prevalence of Listeria spp. in fish obtained from Urmia fish markets. Afr J Microbiol Res 2011, 5(30):5398-5401

40. Davies AR, Capell C, Jehanno D, Nychas GJE, Kirby RM: Incidence of foodborne pathogens on European fish. Food Control 2001, 12(2):67-71.

41. Miettinen $\mathrm{H}$, Wirtanen $\mathrm{G}$ : Prevalence and location of Listeria monocytogenes in farmed rainbow trout. Int J Food Microbiol 2005, 104(2):135-143.

42. Soultos N, Abrahim A, Papageorgiou K, Steris V: Incidence of Listeria spp in fish and environment of fish markets in Northern Greece. Food Control 2007, 18(5):554-557.

43. Yücel N, Balci S: Prevalence of Listeria, Aeromonas, and Vibrio species in fish used for human consumption in Turkey. J Food Prot 2010, 73(2):380-384.

44. Gilot P, Genicot A, André P: Serotyping and esterase typing for analysis of Listeria monocytogenes populations recovered from foodstuffs and from human patients with listeriosis in Belgium. J Clin Microbiol 1996, 34(4):1007-1010.

\section{doi:10.1186/1746-1596-8-149}

Cite this article as: Momtaz and Yadollahi: Molecular characterization of Listeria monocytogenes isolated from fresh seafood samples in Iran. Diagnostic Pathology 2013 8:149.

\section{Submit your next manuscript to BioMed Central and take full advantage of:}

- Convenient online submission

- Thorough peer review

- No space constraints or color figure charges

- Immediate publication on acceptance

- Inclusion in PubMed, CAS, Scopus and Google Scholar

- Research which is freely available for redistribution 